\title{
Relationship between Glyoxylate Cycle and Nitrification Efficiency Based on Heterotrophic Nitrification Bacterium Acinetobacter sp.Y1
}

\author{
Ya-qing LI* \\ College of Environmental Science and Engineering, \\ Taiyuan University of Technology \\ Taiyuan, Shanxi, 030024, China \\ e-mail: liyaqing2005@163.com, \\ www.2015.tyut.edu.cn/cn/index.html
}

\author{
Yu-xiang LIU \\ College of Environmental Science and Engineering, \\ Taiyuan University of Technology \\ Taiyuan, Shanxi, 030024, China
}

\begin{abstract}
The growth and ammonium removal ability of heterotrophic nitrification bacterium are strongly influenced by carbon sources, as well as the activities of key enzymes of glyoxylate cycle. To obtain a better insight into the relationship between glyoxylate cycle and nitrification, the two key enzymes of glyoxylate cycle and the ammonium removal ability of Acinetobacter sp.Y1 grew with different carbon sources were examined. Strain Y1 showed a wide organic carbon substrates, and grew but no nitrify in the medium with sucrose and glycerol as sole carbon source. The strain Y1 showed the most activities of isocitrate lyase and malate synthase when the ammonium removal rate reached highest, and no activities of the two enzymes were detected when the strain grew without nitrification phase. The positive correlation relationship was found between the glyoxylate cycle and nitrification.
\end{abstract}

Keywords-Glyoxylate cycle; Isocitrate lyase; Malate synthase; Heterotrophic nitrification.

\section{INTRODUCTION}

The gloxylate cycle, which was first proposed by Kornberg and Krebs [1,2] in bacteria growing on acetate [3], is an anaplerotic metabolic pathway which plays an important role in the biogenesis of carbohydrates from $\mathrm{C} 2$ compounds $[4,5]$.There are alternative pathways to the glyoxylate cycle in some bacteria [6-8]. This pathway is widespread in living organisms (Bacteria, Eukarya and Archaea), and the two key enzymes (isocitrate lyase and malate synthase) have been detected in various eubacteria, fungi, plants and even some animals $[4,6]$.

There are two key specific enzymes in the gloxylate cycle, isocitrate lyase and malate synthase [1]. Dixon and Kornberg were the first to demonstrate the occurrence of the two key enzymes [9, 10]. Isocitrate lyase, catalyzing the cleavage of D-isocitrate to glyoxylate and succinate; and malate synthase, catalyzing the formation of L-malate from glyoxylate and acetyl-CoA [6].The gloxylate cycle contributes the formation of a $\mathrm{C} 4$ compound from two acetyl-CoA (C2) molecules in each cycle [6].

Nitrification is a microbial process by which ammonium oxidized to nitrate, and plays an important role in maintaining the global environment [11]. There are some heterotrophic microorganisms grow with nitrification. Among them are several fungi, actinomycetes and bacteria. They can use different kinds of organic and inorganic substances as $\mathrm{N}$-source for nitrification to produce nitrite or nitrate $[12,13]$. Most fungi excrete mainly nitrate, while most bacteria and actinomycetes main product nitrite. Some heterotrophic bacteria oxidize ammonium to nitrite or nitrate at rates almost comparable to those of autotrophic nitrifying bacteria [14-17].

Ammoniam treatment is an essential key step for sewage treatment to preventing eutrophication caused by the nitrogen. Compared with antotrophic nitrifying bacteria in the traditional wastewater treatment process, the heterotrophic nitrifying bacteria show a higher growth rate and more adaptation in the different environments, which presents an unique advantages for wastewater treatment [18, 19]. Wastewater, such as domestic sewage and industrial wastewater, contains not only a wealth of nitrogen substances, but also a wide variety of carbon sources. However, the nitrifying activity is often affected by the factors such as $\mathrm{pH}$, temperature and nutrient sources. The living conditions can restrict bacterial growth and nitrification. Energy from different carbon sources are required for different strains to synthetic their own material and nitrification, Thus the carbon source impact the denitrification characteristics of heterotrophic nitrifying bacteria greatly. Many studies have done on the influence of carbon sources to the heterotrophic nitrifying bacteria. For example, Arthrobacter sp. grew with a wide variety of organic carbon sources, but the organism formed nitrite from ammonium only when citrate, malate, acetate or ethanol as carbon source [12]. The nitrifying activity of Alcaligenes faecalis $\mathrm{OKK}_{117}$ increased obviously when pyruvate or oxaloacetate as the sole carbon [14]. However, very little is known on the in vivo response of bacterias under different carbon sources. While, less attention has been paid to the glucose metabolism affected by different carbon sources of the bacterial.

To date, there has only been scarce evidence for the relationship between the activity of the key enzymes in the gloxylate cycle and the efficiency of ammonia nitrogen removal rates in heterotrophic microorganisms [14]. In this study, we characterized the glyoxylate cycle enzymes in Acinetobacter sp.Y1 under different conditions with a wide variety of organic carbon sources, and detected the excess ammonium in the medium, to obtain a better insight into a possible explanation for the different nitrification patterns 
during growth is based on the regulatory properties of gloxylate cycle enzymes.

\section{MATERIALS AND METHODS}

\section{A. Culture Conditions and Cell Extracts}

Acinetobacter sp.Y1 was obtained from coking wastewater and grown aerobically at $30^{\circ} \mathrm{C}$ on a rotary shaker at $120 \mathrm{rpm}$, and in a chemically defined medium contained ( $\mathrm{g} / \mathrm{L}$ distilled water): 4.902 sodium acetate $2 \mathrm{H}_{2} \mathrm{O}$ as sole carbon source, $0.472\left(\mathrm{NH}_{4}\right) 2 \mathrm{SO}_{4}, 0.05 \mathrm{MgSO}_{4} \cdot 7 \mathrm{H} 2 \mathrm{O}, 0.2$ $\mathrm{K}_{2} \mathrm{HPO}_{4}, 0.12 \mathrm{NaCl}, 0.01 \mathrm{MnSO}_{4} \cdot 4 \mathrm{H}_{2} \mathrm{O}, 0.01 \mathrm{FeSO}_{4} \cdot 7 \mathrm{H}_{2} \mathrm{O}$, $\mathrm{pH} 7.0$ (According to Stephenson medium $[18,20]$ ). The medium was autoclaved for $20 \min$ at $121{ }^{\circ} \mathrm{C}$.

For experiments with washed cell suspensions, the cell were grown in $500 \mathrm{~mL}$ Erlenmeyer flasks containing $200 \mathrm{~mL}$ of medium above (1\% of the cell inoculum) at $30^{\circ} \mathrm{C}$ on a rotary shaker at $120 \mathrm{rpm}$, harvested under sterile conditions in the logarithmic growth phase by centrifugation (10 min, $10000 \times \mathrm{g})$, washed three times with Tris- $\mathrm{HCl}$ buffer $(0.05 \mathrm{M}$, $\mathrm{pH}$ 7.7), and resuspended in $5 \mathrm{~mL}$ of the same buffer, lysed by sonication in a bath of ice. Cell debris was removed by centrifugation $\left(20 \mathrm{~min}, 15000 \times \mathrm{g}, 4^{\circ} \mathrm{C}\right)$, and supernatant was used for enzyme assays.

\section{B. Enzyme Assays and Determination of Protein Concentration}

Isocitrate lyase activity was measured according to Mcfadden and Ching [21-23]. ICL reaction, the cleavage reaction of isocitrate to succinate and glyoxylate, was assayed by measuring the formation of glyoxylate phenylhydrazine in the presence of isocitrate and dinitrophenylhydrazine at $30^{\circ} \mathrm{C}$. The reaction mixture contained $1 \mathrm{~mL}$ Tris- $\mathrm{HCl}$ buffer (0.05 M, pH 7.7), $0.2 \mathrm{~mL}$ L-CysteineHCl $(60 \mu \mathrm{M}), 0.5 \mathrm{~mL}$ D-isocitrate $(7 \mathrm{mM})$, and $0.5 \mathrm{~mL}$ enzyme solution. The reaction was started by the addition of D-isocitrate, and stopped by the addition of $0.5 \mathrm{~mL} 10 \%$ Trichloroaceticacid. $0.2 \mathrm{~mL} 0.1 \%$ dinitrophenylhydrazine and $2 \mathrm{~mL} \mathrm{NaOH}(1.5$ M) were added to $1 \mathrm{~mL}$ of the reaction solution. The activity was detected according to the rate of formation of glyoxylate phenylhydrazine in absorbance at $445 \mathrm{~nm}$. One unit (U) of enzyme activity is defined as the amount of enzyme necessary to produce $1 \mu \mathrm{mol}$ of glyoxylate phenylhydrazine per minute under assay conditions.

Malate synthase activity was measured according to Cook $[1,24]$.MS reaction, the synthesis reaction of acetyl$\mathrm{CoA}$ and glyoxylate to L-malate, was assayed by measuring the degradation of acetyl-CoA at $30^{\circ} \mathrm{C}$.The reaction mixture of $1 \mathrm{~mL}$ volume consisted $100 \mathrm{mM}$ Tris- $\mathrm{HCl}$ buffer, $\mathrm{pH}$ $8.0,10 \mathrm{mM} \mathrm{MgCl} 2,1 \mathrm{mM}$ glyoxylate, $150 \mu \mathrm{M}$ acetyl-CoA, and the enzyme solution. The reaction was started by the addition of acetyl-CoA. The activity was detected according to the rate of degradation of acetyl-CoA in absorbance at 232 $\mathrm{nm}$. One unit (U) of enzyme activity is defined as the amount of enzyme necessary to consume $1 \mu \mathrm{mol}$ of acetyl-CoA per minute under assay conditions.

Protein concentration was determined as described by Bradford [6, 25], using boving serum albumin as standard.

\section{Ammonium Analysis}

Growth of the bacterium was monitored by measuring the optical density $\left(\mathrm{OD}_{600}\right)$ using a spectrophotometer at 600 $\mathrm{nm}$.

Ammonium analysis was performed by the method of Nessler' reagent photometry, containing $25 \mathrm{~mL}$ culture supernatant mixed with $500 \mu \mathrm{L}$ potassium sodium tartrate and $750 \mu \mathrm{L}$ Nessler' reagent, measuring the concentrations of ammonium $\left(\mathrm{NH}_{4}-\mathrm{N}\right)$ at $420 \mathrm{~nm}$ after 10 min against a blank with distilled water treated as above.

\section{RESULTS AND DISCUSSION}

\section{A. Effect of Different Carbon Sources}

To find the influence of carbon source on the nitrogen removal performance and glyoxylate cycle for heterotrophic nitrification bacteria. The isolated strains, $A$. faecalis $\mathrm{C}_{16}$ and Acinetobacter sp.Y1, were cultured in the chemically defined medium mentioned above with the substitution of sodium citrate by different carbon sources at the same moles of carbon. In the medium, the amount of $\left(\mathrm{NH}_{4}\right) \mathrm{SO}_{4}$ (as sole nitrogen source) was fixed, providing $100 \mathrm{mg} \cdot \mathrm{L}-1 \mathrm{NH} 4-\mathrm{N}$. And glucose, glycerol, ethanol, succinic acid, fumaric acid, pyruvate, sodium citrate, malic acid, sodium acetate or sucrose as the sole carbon source, $\mathrm{C} / \mathrm{N}$ ratio was 14 .Strain $\mathrm{C} 16$ and strain $\mathrm{Y} 1$ were incubated at $30^{\circ} \mathrm{C}$ under aerobic condition on a rotary shaker at $120 \mathrm{rpm}$, respectively. The fact that the ammonium removal ability of heterotrophic bacterium is strongly influenced by carbon sources have been confirmed [27]. The growth and nitrification ability of strain C16 and strain Y1 with different carbon sources were showed in Table 1.

TABLE I. THE GROWTH AND AMMONIUM REMOVAL ABILITY OF STRAIN Y1

\begin{tabular}{cccc}
\hline $\begin{array}{c}\text { Carbon } \\
\text { source }\end{array}$ & $\mathrm{OD}_{600}$ & $\begin{array}{c}\text { Initial NH} 4^{-} \\
\mathrm{N} \\
\left(\mathrm{mg} \cdot \mathrm{L}^{-1}\right)\end{array}$ & $\begin{array}{c}\text { Ammonium removal } \\
\text { rate }(\%)\end{array}$ \\
\hline $\begin{array}{c}\text { succinic acid } \\
\text { Fumaric acid }\end{array}$ & 0.954 & 123.263 & 77.6 \\
Pyruvate & 0.968 & 130.841 & 85.9 \\
Sodium & 1.146 & 111.139 & 95.7 \\
$\quad$ citrate & 0.958 & 126.295 & 84.4 \\
Malic acid & 0.804 & 128.820 & 62.7 \\
Sodium & 0.782 & 127.305 & 61.5 \\
acetate & & & \\
Sucrose & 0.465 & 125.789 & 1.6 \\
Glycerol & 0.296 & 125.789 & 1.2 \\
Glucose & 0.025 & 124.377 & 1.3 \\
Ethanol & 0.022 & 114.758 & 1.8 \\
\hline
\end{tabular}

Shown in Table 1, the $\mathrm{OD}_{600}$ values presented that strain Y1 can use 8 kinds of those carbon sources. And showed wide organic carbon substrates, and grew better with pyruvate, fumaric acid, sodium citrate and succinic acid as sole carbon source. Strain Y1 failed to grow on the medium with glucose or ethanol as sole carbon source. Organic carbon sources are required to process necessary energy during the growth of heterotrophic nitrification bacteria for its growth and nitrification. But some organic carbon cannot be used as the carbon source for the growth of strains. The ammonium removal rate showed different ammonium 
removal ability of the strain Y1 in different carbon sources. Although strain Y1 grew in the medium with sucrose and glycerol, the ammonium removal ability was not detected. The possible explanation for the difference could be energy from different carbon sources are required for different strains to synthetic their own material and nitrification.

\section{B. Relationship between Heterotrophic Nitrification and Glyoxylate Cycle}

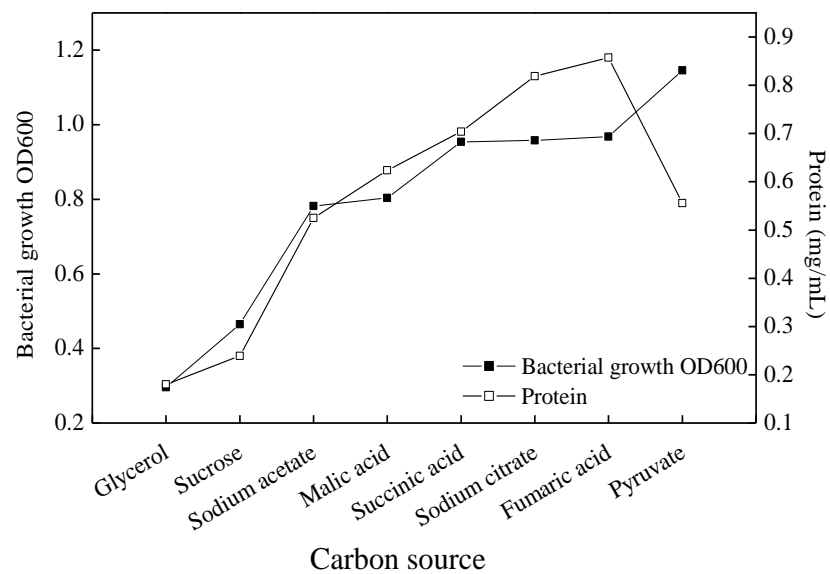

Figure 1. The effects of carbon sources on the bacterial growth by strain Y1

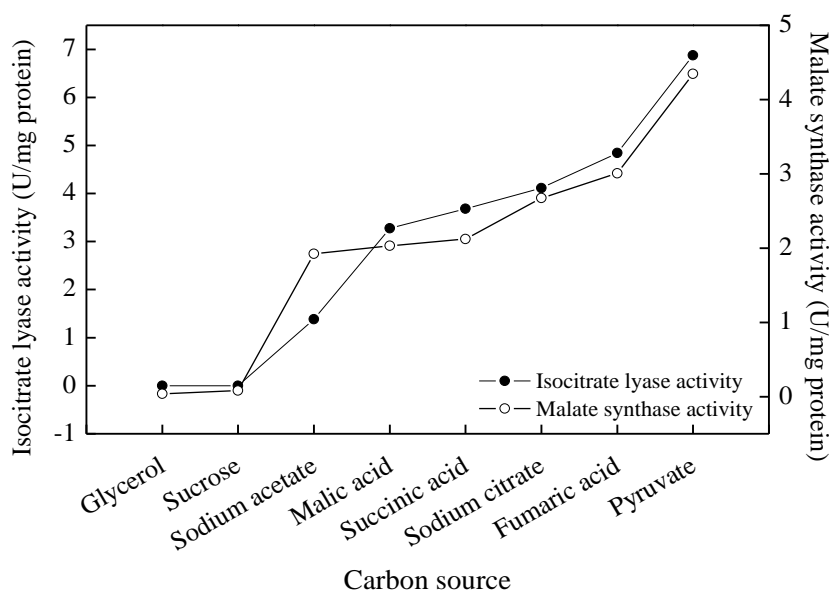

Figure 2. The effects of carbon sources on the key enzyme activities of the glyoxylate cycle by strain Y1

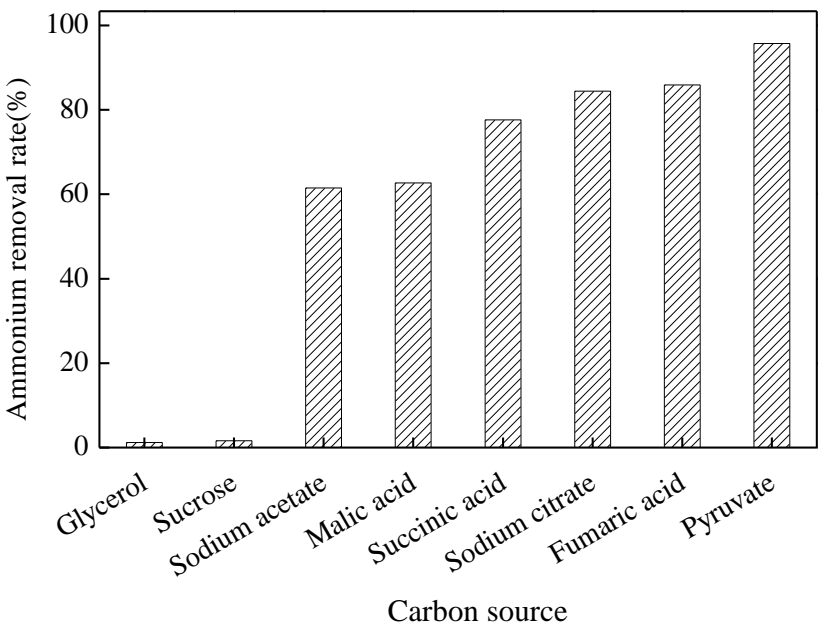

Figure 3. The effects of carbon sources on the ammonium removal ability by strain $\mathrm{Y} 1$

As previously mentioned, the growth of heterotrophic nitrification bacteria was strongly influenced by carbon sources. The thalli was harvested in the logarithmic growth phase for measuring the activities of the two key enzymes of glyoxylate cycle and the ammonium removal ability. Shown in Fig.1, Fig.2, and Fig.3, the ammonium removal ability and key enzymes activities of the glyoxylate cycle were also strictly affected by different carbon sources. The biomass of strain Y1 (Fig.1) was highest when pyruvate as the sole carbon source, and the maximum activity of the two key enzymes of glyoxylate cycle was detected, accordingly. The activity of isocitrate lyase and malate synthase was $6.877 \mathrm{U} / \mathrm{mg}$ and $4.346 \mathrm{U} / \mathrm{mg}$, respectively at the same time; the ammonium removal rate was highest, reached $95.7 \%$ with the same carbon source. However, the activity of the two key enzymes of strain Y1 was nearly nil when sucrose and glycerol as sole carbon, and the ammonia nitrogen removal rate was only $1.6 \%$ and $1.2 \%$ respectively, probably due to different metabolic pathways. This may be explained by the regulative properties of the glyoxylate cycle key enzymes which are induced by pyruvate, and may be repressed by sucrose and glycerol. There was a well correlation between the gloxylate cycle enzymes ammonia nitrogen removal rate by strain Y1.In the medium with different carbon sources, the two enzymes activities of the glyoxylate cycle and the specific nitrifying activity were different by strain Y1.However, when the high activities of the two key enzymes were detected, the strain Y1 showed a high ammonium removal ability, accordingly. The results showed that glyoxylate cycle could have a positive effect on nitrification of strain Y1. 


\section{CONCLUSION}

Results from the present study clearly showed that the growth and ammonium removal ability of heterotrophic nitrification bacteria are strongly influenced by carbon sources. The gloxylate cycle is very important especially under carbon limiting conditions. A possible explanation is that the intracellular level of enzymes depends on the carbon source in the growth medium. There was a well correlation between the gloxylate cycle enzymes and ammonia nitrogen removal rates. Nitrification efficiency was affected by carbon sources. Isocitrate lyase and malate synthase were most active during the nitrification phase, and the glyoxylate cycle also have a positive effect on nitrification. The organic carbon sources are the key metabolites that regulate the activity of the glyoxylate cycle, energy generated by metabolism would be used to detoxify the ammonia during active growth of the organism.

Having shown the significant relationship between the two enzymes activities of the glyoxylate cycle and the ammonium removal ability, we are left with the question of how the organic carbon sources affect the metabolism of heterotrophic nitrification bacteria and the mechanism for glyoxylate cycle affecting the specific nitrifying activity. Explanation of this interesting phenomenon will require further work.

\section{ACKNOWLEDGMENT}

This study was supported by the National Natural Scientific Foundation of China (No.51078252), International Cooperation Projects of Shanxi Province (2010081018) and Nature Science Foundation of Shanxi Province (2010011016-1).

\section{REFERENCES}

[1] Nakazawa, M., T. Minami, K. Teramura, S. Kumamoto, S. Hanato, S. Takenaka, M. Ueda, H. Inui, Y. Nakano, and K. Miyatake (2005)Molecular characterization of a bifunctional glyoxylate cycle enzyme, malate synthase/isocitrate lyase, in Euglena gracilis. Comparative Biochemistry and Physiology Part B: Biochemistry and Molecular Biology. 141(4):445-452.

[2] Kornberg, H.,and H. Krebs(1957)Synthesis of cell constituents from C2-units by a modified tricarboxylic acid cycle. nature. 179(4568):988.

[3] Popov,V.N.,A.U.Igamberdiev,C.Schnarrenberger,S.V.Volvenkin(199 6)Induction of glyoxylate cycle enzymes in rat liver upon food starvation. FEBS letters. 390(3):258-260.

[4] Hüttner, S., D. Mecke, and K.U. Fröhlich (1997)Gene cloning and sequencing, and enzyme purification of the malate synthase of Streptomyces arenae. Gene. 188(2):239-246.

[5] Kornberg, H.(1966)The role and control of the glyoxylate cycle in Escherichia coli. Biochemical Journal. 99(1):1.

[6] Serrano, J.A., M. Camacho, and M.J. Bonete (1998) Operation of glyoxylate cycle in halophilic archaea: presence of malate synthase and isocitrate lyase in Haloferax volcanii.FEBS letters. 434(1):13-16.

[7] Chistoserdova, L.V., and M.E. Lidstrom (1996)Molecular characterization of a chromosomal region involved in the oxidation of acetyl-CoA to glyoxylate in the isocitrate-lyase-negative methylotroph Methylobacterium extorquens AM1.Microbiology. 142(6): 1459-1468.

[8] Han, L., and K.A. Reynolds(1997)A novel alternate anaplerotic pathway to the glyoxylate cycle in streptomycetes. Journal of bacteriology. 179(16):5157-5164.

[9] Claassen, P.A., and A.J. Zehnder (1986) Isocitrate lyase activity in Thiobacillus versutus grown anaerobically on acetate and nitrate. Journal of general microbiology. 132(11):3179-3185.

[10] Dixon, G., and H. Kornberg(1959)Assay methods for key enzymes of the glyoxylate cycle. Biochem J. 72(3).

[11] Watsuji, T.-o., N. Takaya, A. Nakamura, and H. Shoun (2003)A possible role of NADPH-dependent cytochrome P450nor isozyme in glycolysis under denitrifying conditions. Bioscience, biotechnology, and biochemistry. 67(5):1109-1114.

[12] Witzel, K.P. , and H.J. Overbeck(1979)Heterotrophic nitrification by Arthrobacter sp.(strain 9006) as influenced by different cultural conditions, growth state and acetate metabolism. Archives of Microbiology. 122(2):137-143.

[13] Focht, D.D., and W. Verstraete (1977)Biochemical ecology of nitrification and denitrification [Soils].Advances in microbial ecology. 1.

[14] Nishio, T., T. Yoshikura, K. Chiba, and Z. Inouye(1994)Effects of organic acids on heterotrophic nitrification by Alcaligenes faecalis OKK17.Bioscience, biotechnology, and biochemistry. 58(9):1574.

[15] Robertson, L.A., and J. Gijs Kuenen (1992)The effect of electron acceptor variations on the behaviour of Thiosphaera pantotropha and Paracoccus denitrificans in pure and mixed cultures. FEMS Microbiology Letters. 86(3):221-228.

[16] Papen, H., R. Von Berg, I. Hinkel, B. Thoene, and H. Rennenberg (1989)Heterotrophic nitrification by Alcaligenes faecalis: NO2-, NO3-, N2O, and NO production in exponentially growing cultures. Applied and environmental microbiology. 55(8):2068-2072.

[17] Van Niel, E., K. Braber, L. Robertson, and J. Kuenen (1992) Heterotrophic nitrification and aerobic denitrification inAlcaligenes faecalis strain TUD. Antonie van Leeuwenhoek. 62(3):231-237.

[18] Lv, Y.K., W.X un, L. Bokai, L. Yuxiang, and Y. Xiaohua (2012)Isolation and Characterization of Heterotrophic Nitrifying Strain W1.Chinese Journal of Chemical Engineering. 20(5):995-1002.

[19] Brierley. E, and M. Wood(2001)Heterotrophic nitrification in an acid forest soil: isolation and characterisation of a nitrifying bacterium. Soil Biology and Biochemistry. 33(10):1403-1409.

[20] Li, Z.G., L. Yongming, and Teng, Y. (2008) Soil and Environmental Microorganisms Study, Science Press, Beijing, China.

[21] Zhang, B.Z (1988)Determination of isocitrate lyase activity in seeds. Plant Physiology Communications. 3:031.

[22] Roche, T., and B. McFadden(1969)Active site modification of isocitrate lyase. Biochemical and biophysical research communications. 37(2):239-246.

[23] Ching, T.M.(1966)Compositional changes of Douglas fir seeds during germination. Plant physiology.1313-1319.

[24] Cook, J.(1970)Properties of partially purified malate synthase from Euglena gracilis. Journal of Eukaryotic Microbiology. 17(2):232-235.

[25] Bradford, M.M.(1976)A rapid and sensitive method for the quantitation of microgram quantities of protein utilizing the principle of protein-dye binding. Analytical biochemistry. 72(1):248-254 .

[26] Uhrigshardt, H., M. Walden, H. John, A. Petersen, and S. Anemüller (2002)Evidence for an operative glyoxylate cycle in the thermoacidophilic crenarchaeon Sulfolobus acidocaldarius. FEBS letters. 513(2):223-229.

[27] Zhang, L.C., and W. Chunrong (2012) Influence of different carbon sources on nitrogen and phosphorus removal performances of 4 kinds of nitrosation denitrifying phosphorus accumulating bacteria. Industrial water and wastewater. 6:004. 